Received: 06.05.2014.

Reviewed paper

UDK: 316.627:37.035

\title{
PEDAGOGICAL UNDERSTANDING OF EMPATHY AS AN ASPECT OF SOCIAL COMPETENCE
}

\author{
Alma Malkić Aličković, $\mathrm{PhD}$ \\ University of Tuzla Faculty of Philosophy \\ almamalki@yahoo.de
}

\section{SUMMARY}

Socially competent behavior of an individual presupposes success in social functioning in a way where own needs and goals are satisfied, while taking into account the needs of others. The basic requirement for the realization of this behavior is represented in the individual's sensibility for emotional states of others and understanding of their life circumstances in general. This paper, therefore, views empathy as one of the aspects of social competence, and presents different approaches for the determination and understanding of social competence, with a focus on Integrative Model of Understanding Social Competence, authored by Rose-Krasnor. Described as well are different notions of empathy and its development, with special attention paid to the role of pedagogical intervention in this regard.

Keywords: social competence, social skills, empathy.

\section{INTRODUCTION}

In accordance with the different approaches to the understanding of social competence in the literature exists large range of definitions of this term. So Waters and Stroufe (1983, according to Katz and McClellan, 1999) generally define competence as the ability to generate and coordinate flexible, adaptive responses to the demands of the environment, while Mlinarević and Thomas $(2010,143)$ under the concept of competence include "proven ability to use knowledge, skills and other social and / or other skills in work or study situations and in professional and personal development, the ability to understand others and successfully functioning in interpersonal relationships." Social competence according to McFall (1982, according to Pinheiro Mota et al., 2011) reflects the social assessment of the overall quality of an individual's behavior in a social situation, and Joksimovic (2004) under social competence includes having the knowledge and skills necessary for successful interaction with others, such as: understanding and respecting the needs of others, empathy, awareness of the consequences of their own actions on others, and conflict resolution skills.

In the above mentioned understandings of social competence two fundamental approaches to their study are reflected as follows:

- Approach in which social competence is treated as a collection of individual skills and abilities and

- An integrative approach, under which an integral part of social competence, in addition to individual skills and abilities that make it, is represented by their successful application in interaction with others.

From the perspective of both of these approaches an important aspect of socially competent behavior is the empathy that is based on sensitivity to the feelings and needs of others, 
which is the basis for the realization of high-quality interpersonal relationships. Interpersonal relationship aside for being the "space" for manifestations of social competence, also represents a training ground for learning and practicing of skills that make up the repertoire of socially competent behavior. Therefore, to gain an understanding of empathy and social competence at all, it is necessary to examine pedagogical relationships within the family, school and the wider social context of the individual.

\section{APPROACHES TO UNDERSTANDING SOCIAL COMPETENCE}

The basic starting point for the study of social competence is reflected in the consideration of a relationship between social competence, on the one side, and individual social skills and abilities, on the other side.

Proponents of the approach that social competence is the "sum" of different skills and abilities, tried to define social competence by naming 29 indicators that best reflect it. (Meissels et al., 1996).

These indicators are:

1. Developed self-image and strengthening of identity;

2. Self-image as a factor of initiative and control;

3. Habits of personal preservation and self-care;

4. Realistic self presentation, coupled with the feeling of self-worth;

5. Identification of feelings and assessment of their manifestation and consequences;

6. Social sensitivity and understanding of social relations;

7. Positive and caring social relations;

8. Perception and understanding of the roles;

9. Acceptable governing of asocial behavior;

10. Morality and pro-social tendencies;

11. Curious and exploratory behavior;

12. Control of attention;

13. Perceptual abilities;

14. Fine motor skills;

15. Gross motor skills;

16. Perceptual-motor skills;

17. Language abilities;

18. Categorization capabilities;

19. The ability to memorize;

20. Critical thinking ability;

21. Creative thinking ability;

22. Problem solving ability;

23. Flexibility in the application of information - the ability to process;

24. Concept of quantity and ratios;

25. General knowledge;

26. Competitive spirit;

27. Ability to use sources of knowledge and problem-solving;

28. Positive attitudes toward learning and school;

29. Enjoying games and imagination.

This definition of social competence did not contribute to its complete understanding, and one of the biggest problems in the framework of this approach is a way of determining the behavior that would be considered socially competent (Meissels et al., 1996).

Most stringent criticism of the approach according to which social competence is reduced to the sum of many different social skills, gave Rose Krasnor. This author considers treating social competence as the sum of social skills and abilities reductionist, because in this case, social 
competences are located within the individual and are considered to be his or her personality traits, while the interactions between individuals are not taken into account. Also, she emphasizes that this approach can lead us to focus on the individual behaviors and person may seem competent, without that person being capable to integrate all of these behaviors, skills and capabilities into a whole and to behave socially competent (Rose-Krasnor, 1997). Similar understanding is shared by Sheridan and Walker (1999, according to Warnes et al., 2005) who consider that it is not enough that the person possesses the skills needed for successful interaction with others, but also needs to be able to use these skills in a way that is acceptable both for them and for the other people in its environment. In response to the reduction of social competence to some of its aspects, Rose-Krasnor offers an integrative model of social competence. This model in the literature is known as the prism of social competence, and it consists of three hierarchical levels (Figure 1).

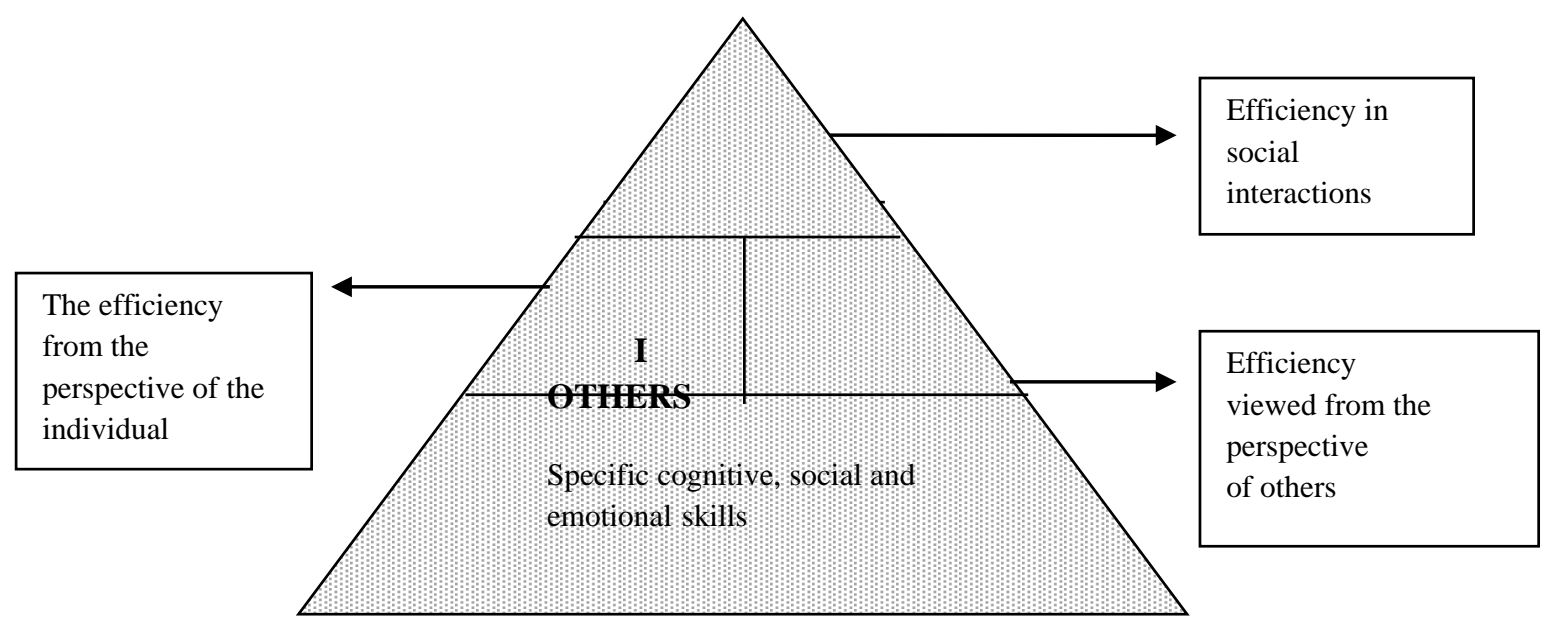

Figure 1 Prism of social competence ${ }^{1}$

At the highest level of hierarchy in this model social competence is defined as efficiency in social interactions, which is a joint product of relations between the individual and his social environment, and the author suggests that we can only discuss social competence through relationships with other people, but stresses that the social competence is contextually conditioned and relative to specific goals. Prisms medium level differentiates between self and others (I and Others), the domain I includes efficiency from the perspective of the individual, and the second domain of the efficiency is of an individual seen from the perspective of others, while the lowest level of prism social competence is determined through specific cognitive, emotional and social skills on which higher levels are based. For this reason, it is wrong to treat any individual ability and skill as social competence, and their importance can only be assessed in the context of the efficiency of an individual in achievement of their social goals (Rose-Krasnor, 1997).

All of the above indicates that a fuller understanding of social competence requires its consideration through the prism of interpersonal relationships, and not just through the presence of specific skills and abilities in the individual which reflect socially competent behavior. In this regard, the importance of empathy should be particularly emphasized, as well as aspects of social competence, which ennobles interpersonal relationships and prevents the phenomenon of social manipulation.

\footnotetext{
${ }^{1}$ Figure taken from: Petrović, J. (2007), Emocionalni temelji socijalne kompetencije, Beograd, pg. 17.
} 


\section{EMPATHY WITHIN SOCIAL COMPETENCE}

Bearing in mind that a successful social functioning of an individual cannot be viewed outside of relationships with other people, and that it involves the fulfillment of their own needs and interests, while respecting the needs of others and alignment of their own behavior in relation to them, an important dimension of social competence is empathy. Empathy allows sensitivity to others' emotional states and their correct interpretation, which makes it "foundation of social skills" (Shapiro, 1997, 47). It allows within the social relationships to obtain information about how people see themselves in a situation that they are in, which can serve as a direction in the choice of words and strategies of behavior for that person (Reardon, 1998).

Etymologically, the term empathy comes from the Greek word "empaso" and "pathe" which means "interweaving oneself into the experience of another" (Bratanić, 1993, 61). Different interpretation of the "interweaving oneself into the experience of another" engendered two basic dilemmas around the concept of empathy. The first concerned the question of whether empathy includes identification, and second, whether empathy is cognitive or affective capacity. Today these dilemmas are outdated and contemporary concepts exclude identification as a component of the concept of empathy, on the grounds that empathy involves sensitivity to others' emotional states, but not the complete identification with the internal frame of reference of another.

This relationship is explained through illustration by Slatina $(1998,50)$ emphasizing that the empathy is sensibility and not sentimentality, and defining it as "understanding encounter of one soul with another soul," whereby empathy is "trial identification" which provides useful hypotheses about "state of mind of another person ", and therefore cannot be characterized as identifying but rather " setting of a single soul for penetrating into another soul." Bratanić (1993, 100) also points out that empathy is not a "sentimental sentimentality, neither giving in or approving," but it involves "understanding and acceptance of a personality such as it is, and it allows discovering of the motives of its behavior and understanding people in the manner that they themselves experienced ". Empathy therefore, means the ability to understand other people who feel and express their feelings, empathic understanding involves understanding what the other person is experiencing in his inner world at a particular moment, but at the same time preserving own identity (Rogers, 1985 by Uzelac and al., 1994).

In a relation to the components that are empathy, today it is clear that empathy involves unique activity of cognitive and affective components. "Empathy is developed parallel with cognitive development, which suggest a connection between cognitive and emotional aspects of the ability to experience the feelings of others and understanding other people's states and perspectives" (Špelić and Zuliani, 2011, 98). It should, however, be pointed out that the theoretical models of empathy research generally follow two directions with respect to whether the researchers emphasize the role of cognition or emotion in empathic experience. Recognizing the importance of oneness of affective and cognitive components of empathic experience Saarni (1999) points out that the existence of a sophisticated understanding of another's emotional state requires:

- To know how to decipher the meaning of common emotional facial expressions,

- To understand the situations which commonly cause emotions,

- To present an awareness of how other people have their own intentions and beliefs, or their own internal states,

- To take into account specific information about others that might make non-stereotypical understandable emotional reaction or response that is different from that to someone else felt the same situation, and

- To know how to name certain emotional experiences, in order to be able to communicate verbally about their own feelings.

Based on the above understanding of empathy, it is evident that the authors emphasize the emotional sensitivity as the basis of empathic behavior, the absence of which mainly stresses as a signal to potential failure in social relationships. So Hubbard and Coie (1994) use of the emotional vocabulary and the ability to recognize emotions consider as the basis of successful 
social functioning. Einsenberg and Mussen (1989, according to Petrovic, 2007) suggest that children are adept at recognizing emotions and simultaneously prone to exercising empathy, which contributes to their acceptance in a group of peers (Eisenberg, Mussen, 1989, according to Petrovic, 2007). On the other hand, deficiencies in understanding other people's emotions are associated with lower levels of social competence and peer acceptance (Cassidy et al., 1992, according to Eisenberg et al., 1999). Lamerise and Arsenio (2000, according to Zotović and Petrovic, 2007) point out that the child who interact with peers accurately detect the type of emotional experience of his counterpart, and is able to behave in a manner appropriate to the situation, while the child who in interaction with peers errs in assessing emotional state, often inadequately reacts which makes the interaction unsuccessful. In children, whose families have not been expressing larger volume of emotion and who do not have enough contact with peers, dysemia or social disadvantage may occur, which is reflected in the lack of interpreting nonverbal cues that govern the interaction. Children with this problem fail to watch people while they are addressing them, and seem tactless in relation to others' emotional state (Goleman, 2008).

Integration of empathy in socially competent behavior is also reflected in the individual's ability to cope with conflict situations. Socially competent behavior includes constructive dealing with conflicts which would be impossible in the absence of empathy, considering that dealing with conflict requires listening and understanding others, as well as patience required for putting in the effort that will lead to a solution acceptable to both sides.

\section{DEVELOPMENT OF EMPATHY AND THE ROLE OF THE PEDAGOGICAL INTERVENTION IN THIS CONTEXT}

The most comprehensive perspective on research of empathy gave Hofman, who believes that empathic behavior is primarily affective, but becomes significantly transformed by the development of the child's cognitive system, therefore incorporation of empathic affect and socio cognitive development results in four developmental levels of empathy as follows:

1. global empathy

2. egocentric empathy

3. empathy for the feelings of others and

4. empathy for one's living conditions.

Global empathy as the first phase of empathy development is characteristic in children in their first year of life. Children at this age do not distinguish themselves and others as separate physical entities, so what happens to others perceive to be happening to them (Raboteg-Saric, 1995). At this stage the baby experiences the other child crying partly as an identical psychological entity to whom they belong, and that crying is considered inception of feelings of empathic distress (Hoffman, 2003).

Egocentric empathy is the second phase in the development of empathy and occurs after the first year of life, when a child understands self and others as separate physical objects and experiences empathy and understanding that the other person is in trouble, and not itself. Internal states of others at this stage still do not differ from their own, so at this age empathy or empathic distress is self-centered motive (Raboteg-Saric, 1995). However, as empathic distress at this age, is triggered by another's distress, Hofman (2003) points out that it can be treated as pro-social motive, if not completely, then at least partially.

Empathy for the feelings of others occurs between the second and third year of life, when the child is aware that other people have their own feelings, different from its own (RabotegSaric, 1995). True empathy for the feelings of others is an important developmental stage because unlike previous developmental stages that are short-lived and disappear at the next stage, it has all the elements of true empathy and continues to grow and develop throughout life (Hoffman, 2003). At first, the feeling with which children can empathize is simple, but as they gain an understanding of the causes, consequences and associated emotions, children can empathize with complex feelings of others (Hoffman, 2003; Shapiro, 1997). Speech development in this context 
is of particular importance because it contributes to the fact that a child can empathize with increasingly complex emotional states (Raboteg-Saric, 1995).

Empathy for one's living conditions as the last developmental phase of empathy occurs in late childhood, when the child becomes aware that other people are experiencing the pleasure and discomfort of not only the immediate situation but also in the wider life conditions and experiences(Raboteg Saric, 1995). It is supposed to be between the ages of five and eight in child's life that children develop the experience of others, as separate individuals with their own history, identity and life, but until the age of nine or ten children are not able to use the information received regarding the previous experience of the person, in order to predict its future states (Gnepp and Gould, 1985, according to Hoffman, 2003). Cognitive development of a child this age allows covering a huge range of situations, which are no longer limited to the physical presence of the victim (Hoffman, 2003). At this stage, children show compassion towards people that they know, and to those who they have never met, and Shapiro (1997) points out that when children begin to show the need to help others who are in trouble then it can be said that they have fully developed skills of empathy.

From the described phases, it is clear that the empathy development is conditioned by the development of a child's ability to separate themselves from others, recognize their own and others' emotional states and needs and try to satisfy them, which is also what makes a prerequisite of socially competent behavior. Therefore we can say that the development of empathy is the basis for the development of social competence, for which cognitive and emotional capacities of the child are not enough, but also require stimulating and educational actions within the surroundings. The family in this sense is of primary importance, because of the family relationships dynamics, which are created by family members with mutual interactions that determine the overall development of the child, including the development of empathy. Parents in the process of developing empathy in children operate through direct and indirect impacts, ie. Giving direct instructions on how to behave in different social settings with other people, on the one side and demonstrating empathetic behavior by example, on the other side. Longo (2001) points out that the achievement of quality relationship between parents and their child is the best way to teach a child how to establish quality relationships with others.

Parental influence on the development of empathy in children is determined by their upbringing and style. So parents with the dominant authoritative educational style, characterized by a balanced representation of love and warmth to the child on one side and setting requirements and boundaries for the child on the other side, contribute to the development of empathic behavior in children. This parenting style forms the environment in which there are basic prerequisites for meeting the child's needs for security, belonging and love, but also the need for respecting his feelings and attitudes, which is the basis for the child's awareness that other people have such a need, that need to be taken into account and adjust their behavior in relation to them. Children of authoritative parents are recognizable by developed social skills and a positive self-image (ValidVukic, 2009). In contrast, parents who prefer authoritarian educational style, which is based on setting the boundaries and request for the child, without explaining the reasons for their use, hinder the development of empathy and general social competence in their children. Parents' emphasis of obedience and the use of power techniques cause the children to be less social (Baldwin, 1995, according to Sremić and Rijevac, 2010). Parents characterized by a permissive educational style, saturated with parental love and care, but with the absence of setting requests, also hinder the development of socially competent behavior. Rubin et al. (1999, according Joksimovic, 2004) suggest that children who are overprotected and overly controlled have tendencies toward socially incompetent behavior, and that parents of aggressive and unpopular children are cold, aggressive or too lenient.

Affective attachment that a child achieves with parents, firstly the mother, is also a factor in the development of empathy in a family atmosphere. Mothers who consistently respond to the needs of the child since the early days of his life, contribute to the development of secure attachment and such self-image of the child, that it sees itself as a person worthy of attention and shows openness to establishing relationships with other people. On the contrary, when there is 
unsecure affective attachment present between mother and child, the child sees itself as a person who is not worthy of people's attention, and in others it recognizes the enemy orientation. Consequently, the absence of a secure attachment between mother-- child, the child's natural potential for development of empathy is suffocated, because one of the basic conditions for learning, as well as manifesting empathic behavior, openness towards other people, is what these children are lacking. Hirschi (1989, according to Ručević, 2011) points out that secure affective attachment has an inhibitory effect on the occurrence of delinquent behavior.

In the family environment next to the parent, it is important to emphasize the role of siblings, and other adult family members in the process of learning empathy, because they are an important source for the child in forms of social behavior, attitudes and beliefs (Pasalic -Kreso, 2012). Summarizing the characteristics of the family environment that stimulate the development of empathy in children Barnett (1978, according to Petrovic, 2007) points out that it is the ambience that:

- Fulfills the emotional needs of the child and discourage excessive concern for himself,

- Encourages the child to express and experience as many different emotions and

- Allows the child to interact with other people who are emotionally sensitive and responsive.

As the child grows up the child's network of social relationships expands and it has an increasing need to learn the skills and competencies that are needed for the realization of highquality interpersonal relationships outside the family. A higher level of cognitive development, which follows the child's age, allows for it, and with starting school relationships with teachers and peers take central place in the process of adopting socially competent behavior. These relationships can be fertile ground for the development of empathy, but also a space for sabotaging its development.

\section{PROBLEMS OF STUDYING AND THE DEVELOPMENT OF EMPATHY AND SOCIAL COMPETENCE IN SCHOOL}

School is a place where most people spend about twenty years of their life (Macionis and Plummer, 1997; according Tufekcic, 2009) at that the most vital years in which person is most capable of learning (Henting, 1997). Therefore, despite all the potential that a child has, school also has the period in which the actualization of these potentials is most convenient, making it the ideal place for developing empathy and social skills. On the other hand, starting with the importance that social skills have for success in life and the definition of school as "a place where people live and gain experience" (Henting, 1997), and understanding of education as "preparation for life" (Neal, 1980), learning and the development of socially competent behavior represent the basic tasks of the school. Pro-social and socially responsible behavior contribute to establishing a positive, academically relevant interactions, which represents the preferred context for the realization of the process of learning and teaching (Spasenović, 2009), and learning to cooperate and develop desirable, pro-social and constructive relations, is as important as learning to read, write or count (Buljubašić-Kuzmanovic, 2009). However, the school that we have today, rooted in practices that put emphasis on cognitive development, can hardly respond to this task, because "cognitive model school insists on the development of the intellect and rationality at the expense of emotional, moral and social development of personality" (Slatina, 2005 205). Effects of cognitive models of school, is best illustrated by an increasing need for the introduction of additional learning programs of socio-emotional skills in school. In the world, an approach called "structured learning of social skills", which can be described as a psychological intervention in which timely effectively content designed to improve social behavior are adopted, is well know (L 'Abate and Milan 1985, according Ajduković and Pecnik, 1998). Salovey et al. (according Munjas Samarin and Takšić, 2009) in 2000 stated about the existence of 300 programs on social and emotional learning in American schools, and about 150 programs on emotional literacy. However, Munjas Samarin and Takšić (2009) warn that as a consequence of the promotion of the need for social and emotional learning in schools, a number of programs that 
are indiscriminately promoted while their theoretical merits and effectiveness are questionable. These authors point out that most of these programs are not designed specifically for the encouragement and development of socio-emotional skills, and that the limiting factors are insufficiently controlled conditions of implementation and program evaluation. The main goal of most programs intended to develop social skills according to Spasenović and Mirko (2007), is reflected in the acquisition and demonstration of social skills, and reduction or elimination of behavioral problems and generalization of social skills. Most common skills that the above mentioned programs seek to develop in children are: listening, initiating and maintaining conversations, asking questions, presenting themselves and others, giving thanks and giving praise, asking for help, involvement, giving and following instructions, expressing feelings of others, responding to others feelings, reacting to others anger and defending of their own rights, etc. (Goldstein et al., 1980, according to Ajduković and Pecnik, 1998).

Settings for the effective development and implementation of emotional intelligence programs, which can be applied in the context of learning and the development of empathy and social competence, are given by Zeider et al. (2002), and these are reflected in the following:

1. Intervention program for the development of emotional intelligence should be based on a solid theoretical framework, allowing for a clear definition of emotional intelligence;

2. Determination of the specific objectives of the program for target population, and definition of outcomes in terms of specific skills that the child will learn;

3. Should be defined in specific educational, social and cultural contexts in which the programs will be implemented (age of the students, the culture, the characteristics of teachers);

4. Programs should not be taught as additions to the regular curriculum, but integrated into the overall academic program of the school to complement it by linking academic lessons about emotions with other subjects;

5. Should allow the generalization of learned skills outside the classroom.

6. It is important to adequately prepare teachers, ie. Train them before and during the implementation of the program.

Although some of the socio-emotional learning programs, which are applied separately from the regular curriculum, have short-term effects, the true advancement of socio-emotional life of children and utilization of their capacity is possible at the school where the socio-emotional learning integrated with academics (Elias et al. , 2001, according to Munjas Samarin and Takšić, 2009), or where the encouragement of the psycho-social behavior development is an integral part of the curriculum, not its supplement (Jovanovic, 2011). Such a perception is shared by Goodwin (1999), noting that social skills and competencies essential for successful functioning in school and outside its walls must be incorporated into the curriculum for all children. For the realization of an approach that involves learning and development of social competence within the "regular school work," the authors propose different strategies, with special emphasis placed on cooperative learning. Spasenović and Mirko (2007) point out that a structured program of cooperative learning, one of the most acceptable strategies of exercising students' social competence, which is carried out with the entire department. With this approach to teaching social and academic knowledge and skills is integrated and is everyday school work, which contributes to academic competence, social functioning of individuals and establishment of social support (Spasenović and Mirko, 2007). As the primary benefits of cooperative learning and teaching Abrami et al. (1995, in Clare, 1998) state that it encourages the development of cooperative forms of behavior, which is reflected in the cooperation and mutual readiness to help, it intensifies the interaction between students and contributes to the development of students' responsibility to achieve a common goal. Ševkušić (2003) states that the research results on cooperative learning suggests that this form of learning can be applied to students of all ages, in all subjects and in a large number of tasks and Jovanovic (2011) argues that school can best contribute to the social 
development of students, if within it work and life take place in a spirit of cooperation, friendship and support, because child, adopts values that are nurtured in an environment in which he lives, easiest.

Especially significant role in the process of developing empathy and socially competent behavior in school belongs to the teacher. Hamilton and Howes (1992, by Simel et al., 2010) point out that when the child starts school teachers take part of the parental role, because children spend more time with them than with their parents. Teachers with their behavior are role models that students mimic and through identification with them acquire characteristics that are permanently retained, which is especially pronounced in the early grades of elementary school, when the influence of teachers is one of the most important factors in the framework of the overall impact of the school on the personality of the child (Lalic, 2002). A teacher who knows and respects the particularities of human nature, is aware of the possibilities for the development of their students, but also their own role in this process, and strives for his students to develop all their potential or as is said in Maslow's style "become what they can be." Such a teacher interacts with students showing patience, respect, empathy and understanding, and encourages initiative, a tendency towards cooperation and mutual understanding, which forms a suitable environment for learning and developing socially competent behavior.

\section{CONCLUSION}

Socially competent individual behavior can be observed only in the framework of its relationships with other people, and it involves the realization of their own interests and goals, while taking into consideration others. A precondition for the realization of such behavior represents empathy, and therefore it may be said that it is one of the most fundamental aspects of social competence.

Within understanding of human nature it is clear that empathy is inherent for humans, and that they are born with this potential for empathic and socially competent behavior, but that the development of these potentials is determined by the quality of pedagogical relationships in the social milieu they are growing up in. Accordingly of special significance are pedagogical relationships in the family and the school, where parents and teachers, in relation to the quality of their pedagogical efforts, may affirm the development of the potential that the child posses naturally or hinder and obstruct it. Given the importance of social competence for successful social functioning and role of the school to empower all of the individuals resources that are necessary for living in a society, learning and development of socially competent behavior should be regarded as one of the fundamental obligations of the school.

\section{REFERENCES}

1.) Ajduković, M., Pečnik, N. (1998). Nenasilno rješavanje sukoba. Zagreb: Alinea.

2.) Bratanić, M. (1993). Mikropedagogija. Zagreb: Školska knjiga.

3.) Buljubašić-Kuzmanović, V. (2009). Kooperativno učenje kao indikator kvalitete odgoja i obrazovanja. Život i škola, 21, 50-57.

4.) Eisenberg, N., Febes, R. A. , Losoya, S. (1999). Emocionalno reagiranje: regulacija, društveni korelati i socijalizacija. U: Salovey, P., Sluyter, D.J. (ur.) Emocionalni razvoj $i$ emocionalna inteligencija (175-220). Zagreb: Educa.

5.) Goodwin, M.W. (1999). Cooperative Learning and Social skills: What Skills to Teach and How to Teach Them. Intervention in School and Clinic, 35 (1), 29-33.

6.) Goleman, D. (2008). Socijalna inteligencija. Beograd: Geopoetika.

7.) Henting, H. (1997). Humana škola. Zagreb: Educa.

8.) Hofman, M. L. (2003). Empatija i moralni razvoj-značaj za brigu i pravdu. Beograd: Dereta.

9.) Hubbard, J. A., Coie, J. D. (1994). Emotional correlates of social competence in children; s peer relationships. Merrill Palmer Quarterly, 40, 1-20. 
10.)Joksimović, S. (2004). Uloga vršnjaka u socijalnom razvoju djece i mladih. U: Socijalno ponašanje učenika (37- 61). Beograd: Institut za pedagoška istraživanja.

11.)Jovanović, M. (2011). Kreiranje pozitivne pedagoške klime u savremenoj školi. Pedagoška stavrnost, 3-4, 256-263.

12.)Katz, L. G., McClellan, D. E. (1999). Poticanje razvoja dječje socijalne kompetencije. Zagreb: Educa.

13.)Klarin, M. (1998). Uticaj podučavanja u malim kooperativnim skupinama na usvajanje znanja i zadovoljstvo studenata, Društvena istraživanja, 4-5, 639-656.

14.)Lalić, N. (2002). Primena nagrade i pohvale u školi. Zbornik Instituta za pedagoška istraživanja, 34, 236-258.

15.)Longo, I. (2001). Roditeljstvo se može učiti. Zagreb: Alinea

16.)Meissels, S. J., Atkins- Burnett, S., Nicholson, J. (1996). Assessment of social competence, adaptive behaviors and approaches to learning with young children. Washington, D. C. : National Center for Education Statistic, U. S. Department of Education.

17.)Mlinarević, V. , Tomas, S. (2010). Partnerstvo roditelja i odgojitelja-čimbenik razvoja socijalne kompetencije djeteta. Magistra Iadertina, 5(5), 143-157.

18.)Munjas Samarin, R., Takšić, V. (2009) programi za poticanje emocionalne i socijalne kompetentnosti kod djece i adolescenata. Suvremena psihologija, 12 (2), 355-371.

19.)Nil, A. S. (1980). Slobodna deca Samerhila. Beograd: Beogradski izdavačko-grafički zavod.

20.)Pašalić-Kreso, A. (2012). Koordinate obiteljskog odgoja. Sarajevo: Filozofski fakultet.

21.)Petrović, J. (2007). Emocionalni temelji socijalne kompetencije. Beograd: Zadužbina Andrejević

22.)Pinheiro Mota, C., Mena Matos, P., Serra Lemos, M. (2011). Psychometric Properties of the Social Skills Questionnaire: Portuguese Adaptation of the Student Form (Grades 7 to 12). The Spanish Journal of Psychology, 14 (1), 486-499.

23.)Popov, I. (2002). Emocionalna inteligencija. Aktuelnosti iz neurologije, psihijatrije $i$ graničnih područja, 1-2, 60-63.

24.)Raboteg-Šarić, Z. (1995). Psihologija altruizma. Zagreb: Alinea.

25.)Reardon, K. K. (1998). Interpersonalna komunikacija. Zagreb: Alinea.

26.)Rose-Krasnor, L. (1997). The nature of social competence: A theoretical Review. Social Development, 6(1), 111-135.

27.)Ručević, S. (2011). Povezanost privrženosti roditeljima s rizičnim i delikventnim ponašanjem kod adolescenata. Društvena istraživanja, 1(111), 167-187.

28.)Saarni, C. (1999). The developmentof emotional competence. New York: GuilfordPress.

29.)Shapiro, L. E. (1997). Kako razviti emocionalnu inteligenciju djeteta. Zagreb: Mozaik knjiga.

30.)Spasenović, V., Mirkov, S. (2007). Interventni programi razvijanja socijalnih vještina učenika. Nastava i vaspitanje, 1, 56-65.

31.)Sindik, J. (2010). Povezanost emocionalne kompetencije te mašte i empatije odgojitelja sa stavovima o darovitoj djeci. Život $i$ škola, 24, 65-90.

32.)Simel, S., Špoljarić, I., Buljubašić-Kuzmanović,V. (2010). Odnos između popularnost i prijateljstva. Život i škola, 23, 91-108.

33.)Slatina, M. (1998). Nastavni metod. Sarajevo: Filozofski fakultet.

34.)Slatina, M. (2005). Od individue do ličnosti. Zenica: Dom štampe.

35.)Spasenović, V. (2009). Kvalitet socijalnih odnosa i školsko postignuće učenika različitog uzrasta. Zbornik instituta za pedagoška istraživanja, 2, 331-348.

36.)Sremić, I., Rijavec, M. (2010). Povezanost percepcije majčinog i očevog roditeljsko ponašanja i školskog uspjeha kod učenika osnovne škole, Odgojne znanosti, 12 (2),347360.

37.)Ševkušić, S. (2003). Kreiranje uslova za kooperativno učenje: osnovni elementi. Zbornik Instituta za pedagoška istraživanja, 35, 94-110. 
38.)Špelić, A., Zuliani, Đ. (2011). Uloga empatije u socijalizaciji djece s teškoćama u razrednim sredinama. Hrvatska revija za rehabilitacijska istraživanja, 47(2), 96-108.

39.)Tufekčić, A. (2009). Škola kao formalna organizacija i proces socijalizacije mladih. Zbornik radova sa Znanstveno-stručne konferencije: Sistem preveniranja socijalnog isključivanja mladih. Zenica: Islamski pedagoški fakultet, 367-398.

40.)Uzelac, M., Bognar, L., Bagić, A. (1994). Budimo prijatelji. Zagreb: Centar za kulturu mira i nenasilja.

41.)Valjan-Vukić, V. (2009). Obitelj i škola-temeljni čimbenici socijalizacije. Magistra Iadertina, 4(4), 172-178.

42.)Warnes, E.D., Sheridan, S. M., Geske, J., Warnes, W.A. (2005). A Contextual Approach to the Assessment of Social Skills: Identifyng Meaningful Behaviors for Social Competence. Psychology in the School, 42(2), 173-187.

43.)Zeidner, M., Matthews, G., Roberts, R.D. (2002). Can emotional intlligence be schooled? A critical review. Educational Psychologist, 37, 215 - 231.

44.)Zotović, M., Petrović, J. (2007). Prihvaćenost u grupi vršnjaka i emocionalna kompetencija djece preadolescentnog uzrasta. Psihologija, 40(3), 431-445. 